\title{
СТИЛІСТИЧНІ ФУНКЦІЇ СТВЕРДЖУВАЛЬНИХ ЧАСТОК В УКРАЇНСЬКІЙ МОВІ
}

Гурко О. В. Стилістичні функції стверджувальних часток в українській мові.

У статті з'ясовано роль і місце стверджувальних часток у системі засобів вираження модальності. Основну увагу зосереджено на характеристиці стилістичних функцій цих слів в українській мові. Установлено, що частка так - багатофункційна й поєднує в собі різні відтінки, зокрема: згоди, висновковості, послідовності дій. У пропонованій роботі виділено значну кількість синонімічних відповідників стверджувальної частки так.

Ключові слова: стверджувальні частки, стилістичні функції, модальність, ствердження, синонімічні відповідники. 
Гурко Е. В. Стилистические функции утвердительных частиц в украинском языке.

В статье выяснена роль и место утвердительных частиц в системе средств выражения модальности. Основное внимание сосредоточено на характеристике стилистических функций этих слов в украинском языке. Установлено, что частица да - многофункциональная и сочетает в себе различные оттенки, в частности: согласия, вывода, последовательности действий. В предлагаемой работе выделено значительное количество синонимических соответствий утвердительной частицы да.

Ключевые слова: утвердительные частицы, стилистические функции, модальность, утверждение, синонимические соответствия.

Hurko O. V. Stylistic functions of affirmative particles in the Ukrainian language.

The article defines the role and place of affirmative particles in the system of expressing modality. The main attention is paid on the characteristics of the stylistic features of these words in the Ukrainian language. The particle yes is multifunctional and combines different meanings, for example, the meaning of agreement, conclusion and sequence of actions. A significant number of synonymous words of affirmative particles are pointed out.

Key words: affirmative particle, stylistic features, modality, statements, synonymous words.

Питання про функційно-синтаксичне вживання стверджувальних часток давно цікавить мовознавців як у загальнотеоретичному, так і в практично-методичному плані. Цю проблему розглядали такі видатні мовознавці, як О. М. Пєшковський, О. О. Шахматов, П. С. Дудик, К. С. Симонова, О. С. Шевчук, І. А. Нагрибельна та ін.

Поява часток у мові зумовлена саме модальністю як одним зі способів вираження думки. Ось чому на доцільності детального вивчення часток наголошував В. В. Виноградов, зокрема, він зазначав: «Можливо, дальше поглиблене вивчення часток спричинить потребуще тісніше пов'язати більшу їх частину із синтаксичною категорією модальності» [1, с. 228].

Модальність $є$ потрібною конструктивною ознакою речення, оскільки в ньому насамперед що-небудь повідомляють i не лише повідомляють, а й виражають ставлення мовця до того, про що повідомлено. Модальні відношення залучають до своєї сфери різноманітні засоби вираження (граматичні, лексико-семантичні та інтонаційні) з різних мовних ресурсів [7, с. 18].

Важливе місце в системі засобів вираження модальності посідають частки. У процесі мовлення частки виконують важливу функцію, виражаючи логіко-семантичні, модальні та емоційні відношення, а також виступаючи як слово- і формотворчий засіб. Група стверджувальних часток одна 3 найдавніших за походженням і чи не найпоширеніша в сучасній українській мові, про що свідчить наявність багатьох синонімічних відповідників. Спеціального 
грунтовного дослідження, присвяченого цій групі часток у сучасному українському мовознавстві, поки що немає. Саме тому мета нашої статті - простежити стилістичні функції стверджувальних часток на матеріалі художньої літератури.

I. Р. Вихованець зазначає, що стверджувальні частки (так, атож, авжеж, аякже, еге, еге ж) підкреслюють і увиразнюють висловлену думку $[10$, с. 821]. Серед них вирізняють погоджувальні частки, функцію яких виконують слова, що належать до інших граматичних категорій: гаразд, добре та частки інших груп: нехай (хай), ну-ну тощо [7, с. 19].

Виникнення літературно-нормативної стверджувальної частки maк пов'язують з омонімічним прислівником. Процес розвитку частки iз прислівника відбувався внаслідок часткової втрати чи послаблення в останньому основного лексичного значення та набуття формальних ознак класу часток. Безумовно, в цьому процесі важливу роль відіграли й інші мовні фактори (інтонація, логічний наголос, порядок слів тощо), за допомогою яких у реченні створюються допоміжні семантичні відтінки [7, с. 19].

Однозвучний з часткою так прислівник способу дії відповідає на питання як? i виконує функцію обставини (частки ж членами речення не бувають): Як же небо захмариться і моєї зірочки не видко, то мені так важко стане, ніби навкруги мене все повимре, $і$ я одна, одна на божсму світі... [5, с. 33]; Тут так гарно, вітрецьь свіжий nодиха [5, с. 32].

Функцію стверджувальної частки прислівник так спочатку виконував у поєднанні із формою 3-ї особи однини теперішнього часу дієслова бути, значення якого було досить послаблене [7, с. 19]: Ta хіба їх кожного згадаєш? Вже коли я вам кажу, щуо говорять, так воно так і є! [9, с. 78]; Хто ж ото йде? Так $і$ є: Семен з старостами! [7, c. 55]. Згодом паралельно функцію стверджувальної частки прислівник почав виконувати самостійно, без допоміжного дієслова: Ой лишенько, батько вже вертаються! Чий справді? Так, так! Вже його лихе несе [5, с. 95].

Частка так виражає згоду з раніше висловленим: Ta, здається, вже й немає нікого такого... Так... [5, с. 245]; Хоч би ж уже землю віддав, все рівно сам нікчемний біля неї ходити. Так [6, с. 457]; Що скрипач та швецьь - периий пиєизь? Та-а-к! - позіхаючи, одмовляв Іван Мойсійович [5, с. 57]. Повторювана частка так служить засобом підсилення ствердження: Шовкун з одного кіния зали протовпився на 
другий - як стіна блідий, задуманий. - Так ... так ие він [5, с. 522]; Так, так, утекла! - промовив він, досада ущииннула за серие [5, с. 146]; Не зрозуміло, щзо ти говориш. Тобто ти паном будеш, чи щзо? Так, так, матушка [9, с. 67]; А поки Сава прийде, треба нам обміркувать. Не один же чоловік, а ціла, мовляв, громада. Треба, щоб змовитись, щоб думка була одна у всіх, а то як прийде Сава, то в нас тоді почнеться суперечка. Так, так! [3, с. 121]. Вона може виконувати функцію еквівалента речення: Так, так... Боротись я не вмію, $i$ не дало життя мені у руки зброї... Я слабкий.. Ах, чи найслабший від усіх [9, с. 233]; Там як розпусте губу, так і не вговтаєш ї̈ [4, с. 37]. У такому значенні частка так стосується речення загалом. Пов'язуючись за змістом із прислівником, вона може вказувати на приблизність: Mpiє, не зрадь! Я так довго до тебе тужсла. Стільки безрадісних днів, стільки безсонних ночей [9, с. 29]; Мріє, не зрадь! Ти ж так довго лила свої чари в серце жадібне моє, сповнилось серие ущерть [9, с. 92]. Поряд з дієсловом-присудком у формі наказового способу так має відтінок спонукальний: Так ось же слухай, стара! [4, с. 124]; Так ми знову покинемо! [3, с. 206]; Так $і$ думай, моя дитино! [9, с. 243].

Дещо відмінне семантичне навантаження стверджувальної частки так у реченнях, в яких мовець підсумовує пережите, побачене, виражаючи своє ставлення до нього. Це своєрідні думки вголос, що завдяки інтонації передають різні емоційні відтінки, наприклад: Ta так йому й треба! Розібрався - так розібрався! Ще ие староста занедужав, довелося за старосту бути, - так куди! - без дрюка і не nідступай. Бач, як панує: гляди мені та гляди!.. Сам погляди - каже Кирило [6, с. 235]; I треба тобі було тим платком очі прикривати? сказав він, почувши важке Одарчине зітхання. - А що? - Та так ... Пропаде ще платок... - звернувся Карпо, щуо б не вражати Одарку нерадісною звісткою [6, с. 235]; Столоначальником буду, а потім, може, й секретарем, чин дадуть, женюся на багатій. Так [3, с. 184].

Найповніше стверджувальна функція частки так виявляється в діалогічній мові в коротких реченнях-відповідях на поставлене запитання. Частка так здатна самостійно формувати комунікативні одиниці без допомоги інших слів, виступаючи позитивною відповіддю на поставлене запитання: Як ні за що? - Так [5, с. 104]; Що Іван тільки вміє брехати? Так [5, с. 67].

Речення-відповідь може виражати ввесь зміст попередньої репліки або його частину: Після Різдва я взяв у вас сорок? Так, сорок! 
[4, c. 323].

$\mathrm{y}$ реченнях 3 питальною інтонацією частка так може виконувати функцію питальної: Так чого тобі тарабанить до тієї розхристаної оселі аж на край села? [9, с. 239]; Ого-го, поздоров боже Йосипа Степановича, то й гроші повсякчас знайдуться, - чи так? [4, с. 134]; Я понесу тебе в зелені гори, - Ти ж так хотіла бачити смереки. - Тепер не хочу. - Так? [9, с. 58]; Куда ти так чимчикуєш? [4, с. 157].

Як бачимо, частка так - багатофункційна. Навіть як стверджувальна вона поєднує в собі різні відтінки, зокрема, згоди: Копійок по десять, а на худий кінець по двадиять копійок. - Так. I Петру Тимофієвичу зо всіми розходами достанеться два мільйона чотириста тисяч [3, с. 124]; Тепер розумію: щоб видно було орден! Так [3, с. 253]; висновковості: Так, так, государине моя! Що ж, Степанидо Михайлівно, ставте на стіл, щео ви там принесли; здається, там усього доволі є, тілько чарки бракує? [4, с. 202]; Тепер так настало: у кого гроші, той і пан! [4, с. 234]; послідовності дій: $A$ поставте сюди ослінчик. Так тепер возьми миску... [9, с. 321]. Стверджувальна частка так може поєднувати в собі також функції емоційно-експресивної частки: Так, сину, так! Добре говорищ 3 батьком, ще й жінку свою навчаєщ [9, с. 234].

3 інших функцій частки так назвемо ще підсилювальновидільну: То се ти так?! Ти, клятий баламуте, ще знатимеш, як зводити русалок! [9, с. 94], підсилювально-питальну: Так заважаю тобі? Не заважаєш. Але ж сватати не будеш? [9, с. 297]; Так не noïdeme? [3, c. 203].

Виразність стверджувального висловлення досягається, безперечно сукупністю лексичних, граматичних та інтонаційних засобів, що переважно виступають одночасно. Однак потрібно зауважити: як один із засобів вираження стверджувальної модальності інтонація у цьому раз відіграє провідну роль, оскільки завдяки ій можна навіть змінити значення слова або зміст висловленого [2, с. 50]. Наприклад, стверджувальною часткою так відповідь може виражати заперечення: Так би я тебе послухала! I не проси, і не говори мені: нічого не хочу слухати! [5, с. 61].

Стверджувальні частки так, гаразд у ролі слів-речень переважно стилістично нейтральні, активно вживані в художніх, наукових та публіцистичних текстах. Вони мають значення позитивної відповіді на поставлене запитання, значення власне згоди, 
тобто це традиційно закріплене, узвичаєне значення слів-речень. За функційним призначенням стверджувальну частку так уживають під час відповіді, що підтверджує правильність думки, наявність явища чи факту, а також виражає згоду на будь-яку дію чи стверджує раніше висловлене. Для передання згоди вживають також частку гаразд. Наприклад: За щзо купив, за те й продаю, що чув - те й вам, добродію кажу. - Гаразд, гаразд [5, с. 441]; Кажіть тільки, щуо ие від земств честь. - Гаразд, гаразд! [6, с. 410].

Слова-речення Так! Гаразд!, крім основного значення «ствердження», подають додаткову інформацію, а саме: 1) уточнюють тип значення «ствердження», зокрема значення власне згоди; 2) визначають ступінь інтенсивності значення, яке передають: високий чи середній ступінь категоричності; 3) вказують на характер стосунків між мовцями: офіційні/напівофіційні.

Інші частки, зокрема ага, авжеж, атож, аякже, отож, еге, угу тощо, характерні для розмовного мовлення, насамперед уснодіалогічного, тому їх уживають для ствердження, вираження згоди або підтвердження чи схвалення чого-небудь [8], наприклад: $A$ ви хочете знати? - Авжеж хочу! [6, с. 329]; Часом - з квасом, а порою - 3 водою? - каже Одарка. - Атож. Чого в світі не буває [6, с. 203]; Tут нам розходитися, - натякнув Проценко. - Ага розходитися? Ну, прощай [6, с. 333]; Ягоди рвала? - Еге. Може вам черешень всипати [5, c. 339].

У розмовному стилі вживають частку авжеж, яка поєднує в собі функції стверджувальної й підсилювальної: Хіба, ви думаєте, трудно навчитись читати? - Авжеж, не легко [5, с. 63]; Чого ж ти боїся! Хіба вже вона так і вкусить! Авжеж, укусить [5, с. 145]; Та, мабуть же, він $i$ здоровий, дуже мильний? - Авжеж сильний: сильніше від усякого звіра [5, с. 288]. Повторювана частка авжеж підсилює ствердження. Вона може виступати також еквівалентом речення: Поведете? - стрепенувся я $і$ заглянув батькові в вічі. Авжежк. Хочеш учитися? [8, с. 209].

Частку атож уживають зазвичай у діалогах як стверджувальну відповідь: За карбованець вісімдесят копійок? - Атожс [8, с. 290]; То ти, Федоре, сам? - Атож [6, с. 127]; Візьмеш за руку яку попівну, поведеш ї̈ в церкву, наречеш своєю жінкою, станеш попом, зів'єш своє кубло та й будеш божу службу правити, народжених хрестити, померших ховати, молодих вінчати? ... Чи як? - Атожс! - оказав Попенко [5, с. 110]. 
Фонетичний варіант частки атож - це отож: Коли Вікентій Петрович підійшов до порома, поромники здивовано перезирнулися між собою. - Отож, - кидає один [8, с. 432]. В окремих варіантах частка отож виконує приєднувальну функцію, здійснюючи зв'язок суміжних думок, висловлених окремими реченнями в монологічній мові; вона може мати і відтінок висновковості.

Частку ага вважають вигуковою за походженням. Вона також може без інших слів виступати позитивною відповіддю на поставлене запитання: Який Чіпка? - А той, що, як навіжений, ганяє по селу... - Аzа! [5, с. 395]; Він зразу пізнав $і$ той голос, $і$ ту пісню... - Ага [5, с. 136], або мати при собі уточнення, пояснення того, про що стверджується: Паночку! Змилосердся! - в один голос простогнала купа. - Ага! Це рибалки? - моргнув на їх Колісник. - Це ті, щзо самовправно рибу з ставка тягали, мов вона їх [6, с. 438]; Оие й усі! Ага, бач, Никифор Іванович [5, с. 513]; Панич кинувся до дверей, а парубок у двері. - Ага, сюди, сюди [5, с. 66].

Функції частки й вигука поєднує слово ага в реченнях, у яких що-небудь згадують: Вона стала під забором передихнути, спочити трохи - Ага! - радісно граючи очима, сказав він, підходячи до неї ... Що, тепер знову на розпутmі? [6, с. 521]. У цій функції частка ага не може бути замінена на так. У функції підсумково-стверджувальної частка ага за значенням повністю відповідає так: Ти думаєщ, щзо я мовчала про це весь час, так я $і$ далі все буду мовчати? Аzа! [8, c. 513].

Частка аякже менш поширена, ніж попередні. Її вживають у розмовній мові, й вона виконує стверджувальну функцію з відтінком запевнення: $А$ щзо в Колісника жила. - Аякжее [6, с. 560]; $A$ тут ще $i$ Оришка підогріває: то забіжить з одного боку, прикро погляне, то з другого - допитується, чи сподобалося у Мар'янівці? - Аякже. Сподобалося, сподобалося [5, с. 513].

Розмовна частка еге виконує стверджувальну функцію: Учора звечора зібрався та з панією й поїхав ... не сказав $і$ куди. - Еге ... Значить, наша правда [5, с. 432]; А в тебе тут як пустка, та темно, та нечисто! - не видержала Христя. - Еге, отак довелося жити [6, с. 510]; Вечеряти? - перепитав він, наближаючись до неї, злегка торкнувся пальцем ї̈ гарячого підборіддя, заглянув у вічі. - Еzе, кличуть, - весело защебетала вона [6, с. 318]. У питальному реченні вона спонукає співрозмовника дати стверджувальну відповідь: Так уяви: це моє рідне місто, і мені ж самому випало його визволяти. Це 
вже скоро рік вийде, еге ж, Брянський? [8, с. 204]. Значне вужче коло вжитку частки угу, яка відзначається послабленою емоційністю: Чого я там у нього не бачила? Мені коли б вернули мою одежу? - Угу. Одежу? [6, с. 524].

У складі стверджувальних часток окремо виділяють групу погоджувальних часток, за допомогою яких не лише стверджують певну думку, а й виражають згоду з пропозицією співрозмовника чи бажання задовольнити його прохання. Зі значенням згоди виступають модальні частки інших груп - спонукальні ну (ну-ну), нехай (хай), а також частки прислівникового походження гаразд, добре. Вони виступають як виразники основного модального значення висловлювань i зазвичай $є$ базовими словами, на фоні яких конкретизують, уточнюють це значення, хоч можуть виконувати цю роль і самостійно залежно від комунікативної потреби: $A$ може, де поля роздобудемо - буде чим засіяти. - Добре, мамо [5, с. 452]; Добре! Тільки на хвилину додому забіжу, бо я ще не бачився $i$ з батьком. Прощай! [5, с. 34); Христя прохала батька привезти з міста гостиния - хоч перестень, хоч сережки, хоч стьожку яку-небудь. Гаразд, добре! [6, с. 85]; Так нехай шарабан розпряжуть. Я поїду сам в бігунках [3, с. 209]; Нy, та нехай вже буде вама зверху [5, с. 36].

Отже, стверджувальні частки - це зазвичай елементи розмовного й художнього мовлення. Вони пожвавлюють мову, роблять ऑï експресивнішою, уточнюють смислове значення самостійних слів у контексті, полегшують розуміння фрази. Стверджувальні частки є своєрідними замінниками речень. На синтаксичному рівні їх сприймають як слова-речення, зміст яких визначений попередньою реплікою-запитанням або розкритий інформацією. У групі стверджувальних часток наявна значна кількість синонімічних відповідників, що є свідченням того, що в основних своїх значеннях ці частки досить близькі.

\section{Література}

1. Виноградов В. В. Избранные труды. Исследования по русской грамматике / В. В. Виноградов. - М., $1975,-560$ с.

2. Дудик П. С. Синтаксис сучасного українського розмовного літературного мовлення / П. С. Дудик. - К. : Наукова думка. -285 с.

3. Карпенко-Карий Іван. Будущина в руках нового покоління. Вибрані твори / Іван Карпенко-Карий. - К. : Країна мрій. - 414 с.

4. Кропивницький Марко. Драматичні твори / Марко Кропивницький. - К. : Наукова думка, 1990. - 608 с.

5. Мирний Панас. Твори в 2-х томах / Панас Мирний. - Т. 1. - К. : Дніпро, 1985. - 552 с.

6. Мирний Панас. Твори в 2-х томах / Панас Мирний. - Т. 2. - К. : Дніпро, 1985. - 562 с. 
7. Симонова К. С. Функції стверджувальних часток в українській мові / К. С. Симонова // Українська мова і література в школі. - 1980. - № 11. - С. 18 - 22.

8. Сучасна українська літературна мова. Морфологія / [за заг. ред. акад. І. К. Білодід]. - К. : Наукова думка, 1969. - 583 с.

9. Українська література : Хрестоматія нововведених творів : у 3-х частинах / [упорядник Р. В. Мовчан]. - Ч. 3. - К. : Генеза, 2003. - 576 с.

10.Українська мова. Енциклопедія / [редкол. В. М. Русанівський, О. О. Тараненко (співголови), М. П. Зяблюк та ін.]. - [3-є вид. зі змінами і доп.]. - К. : Вид-во «Укр. енцикл.» ім. М. П. Бажана, 2007. - 856 с.

11.Шевчук О. С. Стилістичні функції часток / О. С. Шевчук // Українська мова і література в школі. - 1976. - № 5. - С. 24 - 33. 